\title{
Local food supply chain resilience to constitutional change: The Brexit effect
}

\author{
Linda C. Hendry ${ }^{1}$, Mark Stevenson ${ }^{1}$, Jillian MacBryde ${ }^{2}$, Peter Ball ${ }^{2}$, Maysara \\ Sayed ${ }^{3}$, Lingxuan Liu ${ }^{4}$
}

International Journal of Operations and Production Management

Accepted for publication 21 August 2018, DOI 10.1108/IJOPM-03-2018-0184

\begin{abstract}
Purpose: To investigate how local supply chains prepare for and respond to the threats and opportunities presented by constitutional change, thereby building resilience.

Design/methodology/approach: Multiple case study analysis of 14 firms in the food sector is presented in the context of the United Kingdom's impending exit from the European Union (Brexit). Organisations studied include farmers, processors, retailers, and non-government organisations (NGOs). Data from interviews and roundtable discussions has been interpreted using the dynamic capabilities perspective, covering the sensing, seizing, and transforming stages.
\end{abstract}

Findings: The data highlights the importance of both vertical and horizontal collaboration between supply chain actors as they seek to anticipate the impact of the disruption and influence the future shape of the constitution. There is also evidence to suggest firms in possession of dynamic capabilities can innovate to build resilience and enhance their competitive position. Characteristics of the disruption posed by constitutional change are identified and contrast with those of many other threats more typically described in the literature. As a result, the process of building resilience is different.

Research limitations/implications: The study could be extended to include post-Brexit interviews to further understand the seizing and transforming stages whilst the impact of Brexit on actors that remain within the EU could also be considered.

Practical implications: Practitioners need to work together to influence the future shape of the constitution; and they need to reconfigure their operations and supply chains where necessary to become more resilient to the threat posed by Brexit, such as by reducing their reliance on EU funding streams and trade. The study also has policy implications.

Originality/value: The first study of supply chain resilience to constitutional change and a rare empirical study of resilience across multiple supply chain tiers.

Keywords: Supply chain resilience; Brexit; Constitutional change; Dynamic capabilities.

${ }^{1}$ Department of Management Science, Lancaster University Management School, Lancaster

University, Lancaster, UK

2 The York Management School, York, UK

${ }^{3}$ University of Edinburgh Business School, Edinburgh, UK

${ }^{4}$ Pentland Centre for Sustainability, Lancaster University Management School, Lancaster

University, Lancaster, UK

Acknowledgment: This research has been funded by the N8 Agri-food research programme, which in turn is funded by HEFCE and the partner Universities of Lancaster and York. 


\section{Introduction}

Supply Chain Resilience (SCRes) broadly refers to the ability of supply chains to prepare for and/or respond effectively to disruptions, ideally emerging as stronger entities (Sheffi, 2005; Ponomarov \& Holcomb, 2009; Ponis \& Koronis, 2012). Several studies have recently appeared on SCRes, and resilience more broadly, as reviewed by authors such as Hohenstein et al. (2015), Tukamuhabwa et al. (2015), and Stone \& Rahimifard (2018). For example, Tukamuhabwa et al. (2015) found that the SCRes field remains in its infancy with limited empirical research, including a lack of work that examines multiple tiers of a supply chain or network. Meanwhile, although there has been an emphasis on the disruptions to supply chains caused by high-profile catastrophic events such as earthquakes and terrorism, there is a lack of research that considers resilience to constitutional change. This includes resilience to the changes currently being experienced in the United Kingdom (UK) as a result of Brexit, i.e. the UK's planned exit from the European Union (EU). Brexit has the potential to have enormous consequences for firms in the UK, impacting the cost and availability of both supply and demand from Europe and the availability of capacity resources, including migrant workers; and the characteristics of the threat in terms of its probability of impact, the time available to prepare, and the uncertainty of its consequences make it different to many other events studied in the SCRes literature. This paper uses empirical evidence gathered from interviews across multiple tiers of food supply chains, including with farmers, processors, retailers, and non-government organisations (NGOs), to uncover how actors are preparing for and responding to the threats (and opportunities) presented by Brexit; and the resulting data has been interpreted from a dynamic capabilities perspective (Teece et al., 1997).

Local food supply chains, including in the UK, have become increasingly important in the light of global food security concerns, calls for enhanced traceability, increases in food poverty, and political and environmental disruptions to global supply chains. Indeed, the local food concept can be argued to have many competitive advantages, both in terms of business performance and sustainability that suggest it should be encouraged. For example, it addresses environmental sustainability through potential supply network changes that reduce food miles and social sustainability through employment of the local community (Oglethorpe \& Heron, 2013, Czinkota et al., 2014). Yet ongoing, increasing competitive pressures on small local farmers and uncertainty caused by Brexit mean the survival of local food supply chains in the UK may be under threat. Hence, building SCRes for local food systems in particular is increasingly both a key challenge and opportunity. Thus, there is a timely motivation to research the measures needed to sustain and strengthen local food supply chains, thereby building SCRes in this context.

This paper therefore addresses both the timely need to investigate SCRes in the local food context and the gaps identified in the SCRes literature, i.e. to consider resilience in the light of constitutional change in multi-tier supply chains. It examines the impact of Brexit on local food supply chains in the UK with a particular focus on how supply chain actors are preparing for the UK's planned exit from the EU. The study therefore asks the following research question:

How can SCRes be built in local food supply chains during periods of constitutional change? 
The dynamic capabilities theoretical lens that is adopted helps to guide both the data collection process and the analysis of the findings to establish how the actors are 'sensing' the current supply chain context, including developing an understanding of the disruption caused by constitutional change; how they are 'seizing' any associated opportunities; and subsequently how they are 'transforming' their businesses towards being more resilient. The paper contributes to the extant literature on SCRes by providing the first empirical study of how firms are building resilience to constitutional change; by providing a rare study of resilience across multiple supply chain tiers; and by outlining how the characteristics of the threat posed by constitutional change differ from the characteristics of other threats more typically studied in the literature. Moreover, the paper contributes to the literature on dynamic capabilities by highlighting the role of horizontal and vertical collaboration between supply chain actors in the sensing, seizing, and transforming process.

The remainder of this paper is organised as follows. Section 2 presents the theoretical background to the study, including a brief review of relevant literature on SCRes and dynamic capabilities. Section 3 outlines the empirical multi-case study research method adopted before the findings are presented in Section 4. A discussion follows in Section 5 before the paper concludes in Section 6, including implications for practice and future research.

\section{Theoretical Background and Literature Review}

Section 2.1 below briefly describes the importance of the local food supply chain and the need to study this in the context of SCRes. Section 2.2 then reviews the literature on SCRes, drawing on broader resilience theory from other disciplines, and identifies the research gaps to be addressed in this study. Finally, the theoretical lens adopted is justified in Section 2.3.

\subsection{The importance of Local Food Supply Chains}

In recent times, we have seen increasing interest in short food supply chains and local food systems across the EU and beyond. Some of this interest comes in the light of global food security concerns, calls for enhanced traceability, increases in food poverty, and political and environmental disruptions to global supply chains (see for example Maggio et al. 2016). The advantages of local food systems include: fairer prices for farmers, fresh, local and seasonal produce for consumers, a reduced environmental impact, greater traceability and benefits for the local economy as well as community (Augère-Granier, 2016; Brunori et al., 2016). For example, local food systems create jobs in agriculture and food production, but they can also encourage tourism, bringing economic benefits to the region (Oglethorpe \& Heron, 2013, Czinkota et al., 2014). Indeed the current EU rural development policy 2014-2020 offers producers wishing to get involved in local food systems several incentives cofinanced by the European Agricultural Fund for Rural Development (AugèreGranier, 2016).

Unfortunately, competitive pressures on local farmers and uncertainty caused by Brexit mean the survival of local food supply chains in the UK may be under threat. Thus, building SCRes for local food systems in particular is increasingly both a key challenge and opportunity. Thus, there is a timely motivation to research the measures needed to sustain and strengthen local food supply 
chains, thereby building SCRes in this context. The resilience of local and global food systems has received much attention in other fields (e.g. Rockström et al. 2009; Allouche, 2011; Barthel et al., 2015) but only limited attention from an operations and supply chain management perspective (e.g. Leat \& Reveredo-Giha, 2013).

\subsection{Supply Chain Resilience (SCRes) and Broader Resilience Theory}

SCRes is broadly concerned with a supply chain's readiness, effective response to, and recovery from a disruption - returning to the previous level or an even better level of performance (Ponomarov \& Holcomb, 2009; Ponis \& Koronis, 2012; Hohenstein et al., 2015; Tukamuhabwa et al., 2015). While some of the disruptions faced by organisations and supply chains are external, others originate from within the boundaries of the supply chain. The focus of much prior work has been on high-profile external catastrophic events, including devastating earthquakes, fuel crises, political turmoil, diseases, terrorism, and hurricanes (e.g. Mandal, 2012; Scholten et al., 2014). Meanwhile, other work has examined the potential threat of product counterfeiting, which may originate from within or beyond the boundaries of the genuine product's supply chain and is likely to be a continuous threat rather than a one-off large-scale disruption (e.g. Stevenson \& Busby, 2015; de Lima et al., 2018). Yet, to the best of our knowledge, the literature has not considered resilience to external constitutional change, such as that currently being experienced in the UK as a result of Brexit.

Definitions of SCRes by authors such as Stone \& Rahimifard (2018) have built on broader resilience theory that comes from a variety of disciplines. They look in particular at engineering resilience; ecological resilience and adaptive resilience. Holling (1996) defined engineering resilience as the ability of a system to return to its prior state of equilibrium following a disturbance, assuming that the engineering design has predetermined an optimal state to which the system should revert. Definitions of ecological resilience are similar, but differ in assuming that there may be several alternative states of equilibrium, and that the system may return to the original or flip to an acceptable alternative state (Holling, 1973, 1996). In contrast, the concept of adaptive resilience postulates that there cannot be a state of equilibrium in complex socialecological systems, but that instead resilience is cyclical and cumulative developed through the ongoing learning and adaptations made in response to a series of disturbances (Gunderson \& Holling, 2002; Carpenter et al., 2005; Folke et al., 2010; Davoudi, 2012). Stone \& Rahimifard (2018) conclude with a new definition relevant to agri-food supply chains. This definition is adopted here as most relevant to the local food supply chains being studied, and also being the most comprehensive and up-to-date definition currently available. It emphasises the need to ensure the continual supply of food through: (i) anticipation of disruptions; and (ii) strategies to reduce their impact, facilitate rapid recovery, and enable cumulative learning post-disruption. These modes of anticipation and reactive strategies have been the focus of much prior supply chain research employed to build resilience (Ali et al., 2017).

The list of strategies studied in the extant literature includes broad approaches such as improving flexibility, creating redundancy, improving supply chain agility, and enhancing visibility (e.g. Hohenstein et al., 2015). Other, more specific practices include information sharing (Brandon-Jones et al., 2014) and reconfiguring resources (Ambulkar et al., 2015). Meanwhile, this literature also 
highlights the role of supply chain collaboration, appropriate supplier selection, and supply chain network design in developing resilience (e.g. Scholten et al., 2014) - all of which are arguably linked to the motivations behind local sourcing. The strategies available for building resilience have been commonly classified into proactive and reactive strategies, depending on whether they are employed to avoid or recover from a threat (e.g. Hohenstein et al., 2015; Dabhilkar et al., 2016; Tukamuhabwa et al., 2017). For example, building security (e.g. Rice \& Caniato, 2003), increasing visibility (e.g. Pettit et al., 2010; Carvalho et al., 2012; Boone et al., 2013), and supplier development (e.g. Tang, 2006a and $2006 \mathrm{~b})$ can be considered proactive strategies. Meanwhile, logistics re-routing (e.g. Wang et al., 2015), flexibility (e.g. Pettit et al., 2013), and redundancy (e.g. Sheffi \& Rice 2005) can be considered reactive strategies. A broad strategy such as collaboration (e.g. Rice \& Caniato, 2004; Jüttner \& Maklan, 2011; Scholten \& Schilder, 2015) however could potentially be used proactively or reactively depending on the purpose and timing of its deployment. A third category of strategies is incorporated in the classification by Hollnagel (2011) and Ali et al. (2017), i.e. concurrent strategies, which are considered to be rapid, initial responses during a disruption or in the immediate post-disruption phase somewhere between planning and recovery. Meanwhile, other authors adopt completely different classification schemes for strategies, e.g. based on whether a strategy builds robustness or agility (Wieland \& Wallenburg, 2013) or based on whether a strategy is adopted by a single firm or group of actors (Scholten and Schilder, 2015). A more detailed discussion of the strategies firms might adopt to build resilience and how those strategies might be classified is included in Tukamuhabwa et al. (2015 and 2017).

The extant literature is currently dominated by modelling and conceptual work, e.g. with several authors calling for more empirical studies on SCRes (e.g. Ambulkar et al., 2015; Hohenstein et al., 2015). Meanwhile, Kim et al. (2015) argued that resilience should be analysed from a network perspective, with most studies on SCRes being conducted at the firm level. A rare study to examine resilience across a network of interrelated firms was conducted by Tukamuhabwa et al. (2017). This proved important in highlighting the interrelatedness of threats, strategies, and their outcomes; and how threats can migrate from one actor to another across the network. Therefore, not only is more empirical work required but it is argued to be important to look further at resilience across multiple levels of the supply chain.

Some of the few prior case study contributions have focused on specific industries, for example: Johnson et al. (2013) investigated social capital and SCRes in the context of a UK rail crash; and Urciuoli et al. (2014) examined strategies for building the resilience of energy supply chains. There is a need to conduct further in-depth research in particular industries, including the food industry, which has faced a number of disruptions in recent years (e.g. Marucheck et al., 2011). To the best of our knowledge, the only SCRes studies that have explicitly focused on issues in the food industry are the conceptual study by Stone \& Rahimifard (2018), as discussed above, and that by Leat \& Revoredo-Giha (2013). The latter authors presented a case study of a pork supply chain in Scotland with a particular emphasis on the role of collaboration in developing a more resilient agri-food supply system. For example, the authors highlighted the importance of horizontal collaboration between meat processors and vertical collaboration between processors and retailers for 
reducing the vulnerability of the supply chain to disruption. Leat \& RevoredoGiha (2013) noted that there is governmental interest in the concept of resilience in terms of how it relates to sustainable food supply chains and policies (e.g. Scottish Government, 2009, cited in Leat \& Revoredo-Giha, 2013), but government policies and regulations on food are quite different to the consequences of specific, one-off shifts such as Brexit.

Beyond the research specifically on SCRes, there is a broad literature related to the topic of food and disruption. For example, in the context of supply chain uncertainty, Simangunsong et al. (2016) studied a network of firms in the food industry and highlighted the influence of unethical practices on uncertainty, including collusion and parallel interaction between firms at the same tier of the supply chain. This built on a large body of literature on supply chain uncertainty, as reviewed by Simangunsong et al. (2012), including the work of van der Vorst et al. (1998) who focused on managing sources of supply chain uncertainty to improve performance in food supply chains, outlining improvement principles to increase service levels. Meanwhile, Vlajic et al. (2012) focused on the concept of robustness, proposing an integrated framework for the design of robust food supply chains, which the authors applied to a meat supply chain.

From the above it follows that the SCRes literature remains in its infancy. There is thus far only limited empirical research, with few studies looking at specific industries or multiple tiers of the supply chain. Moreover, much of the focus has been on the effects of large-scale catastrophic events such as earthquakes and terrorist attacks, with a need for further research that considers resilience to constitutional change. In addition to these gaps in the literature, there have also been calls for greater use of theory to improve our understanding of SCRes (Tukamuhabwa et al., 2015). The most notable theory frames used to date are the resource based view (e.g. Ponomarov \& Holcomb, 2009), systems theory (e.g. Blackhurst et al., 2011), contingency theory (e.g. Brandon-Jones et al., 2014), and complex adaptive systems theory (e.g. Day, 2014). The wider literature, including the examples above, adds to our understanding of the challenges and disruptions faced by food supply chains and points to the potential of domestic supply chains for avoiding disruption and vulnerability. But even the wider operations and supply chain management literature on food beyond SCRes does not generally consider the impact of constitutional change. Thus this paper addresses these research gaps by undertaking explorative case study research and adopts a dynamic capabilities theoretical framework, as further discussed below.

\subsection{Dynamic Capabilities}

Teece et al. (1997) introduced the concept of dynamic capabilities, advocating that it is the ability of the firm to sense and adapt to changes in the external environment that will be key to sustainability and competitiveness. Thus dynamic capabilities support the renewal of competitive resources on a continuous basis, encouraging firms to 'integrate, build and reconfigure internal and external competencies to address rapidly changing environments' (Teece et al., 1997, p516). Firms are thereby expected both to exploit existing resources and develop new capabilities, in an attempt to increase adaptability, longevity and competitiveness (Eisenhardt \& Martin, 2000).

Dynamic capabilities have been presented as competitive necessities in modern business (Gebauer, 2011; Rojo et al., 2018), including during times of 
economic downturn (Ahn et al., 2018). The concept of dynamic capabilities is not however without criticism. Indeed, the dynamic capabilities literature has been described as tautological (Eisenhardt \& Martin, 2000) and obscure (Gebauer, 2011). Teece et al. (1997) even argued that dynamic capabilities cannot be defined or generalised as that would conflict with the competitive values of scarcity and inimitability upon which resource-based theories are reliant. The authors argued that dynamic capabilities are unique to every firm and may be built upon organisational culture or history (Teece et al., 1997). In an attempt to offer some clarity, Teece (2007) later produced three categories of dynamic capabilities - sensing, seizing and transforming - where:

- Sensing is described by Teece (2007, p1322) as a "scanning, creation, learning and interpretive activity" in which firms recognise opportunities and threats. Gebauer (2011) suggested such activities are undertaken frequently and encouraged market-searching efforts in an attempt to anticipate market developments and customer requirements.

- Seizing follows on from sensing and is about responding to 'sensed' opportunities and threats. Barreto (2010) stressed the need to make sure that such decisions are both timely and market focused.

- Transforming involves the reconfiguration of intangible and tangible assets, often to enhance, combine, or protect firm capabilities (Teece, 2007). It is here where operational efficiency is realised via routines that can adapt to changing environments on a continuous basis (Gebauer, 2011).

Thus dynamic capabilities enhance evolutionary fitness by enabling the creation, extension, and modification of the resource base and in turn generating long-run competitive success (Teece, 2007). Given that we are interested in "evolutionary fitness" during a period of constitutional change, it is argued that the dynamic capabilities perspective represents an appropriate theoretical lens. In particular, the perspective fits well with the discussion in the broader adaptive resilience literature that argues for the need to build capabilities and capacities in order to effectively recover and learn from unexpected events (van der Vegt et al., 2015). Further, there are similarities here with the notion of resilience being concerned with preparation for, response to, and recovery from a disruption (Ponomarov \& Holcomb, 2009; Ponis \& Koronis, 2012). Sensing would ideally take place in the preparation phase before a supply chain is disrupted; seizing may take place before or in response to a threat; and transforming may take place before, during or after a threat has affected a supply chain, or a transformation may mean a threat is avoided altogether. The features of the dynamic capabilities perspective and of SCRes are thus depicted in Figure 1, together constituting the initial research model for this study. This use of the dynamic capabilities extant theory can be described as a 'theory matching' approach, as defined by Zorzini et al. (2015), and adopted by authors such as Pullman \& Dillard (2010). As argued by Zorzini et al. (2015), this approach strengthens the research rigour of the study by adding external validity to the design. Further, a key feature that runs throughout the three phases of the dynamic capabilities approach is an emphasis not only on threats but also on opportunities, and this supports the notion of supply chains potentially emerging as stronger entities. This is also suitable in the context of Brexit and constitutional change in general where there is uncertainty in how the competitive landscape will be altered. Brexit 
presents challenges to supply chains but it may also present new opportunities, providing a stimulus for innovation. Thus we adopt this perspective, with the constructs of sensing, seizing, and transforming being used to aid in the development of the interview protocol and in the subsequent analysis on the resilience of local food supply chains to constitutional change.

\section{Supply Chain Resilience Perspective}
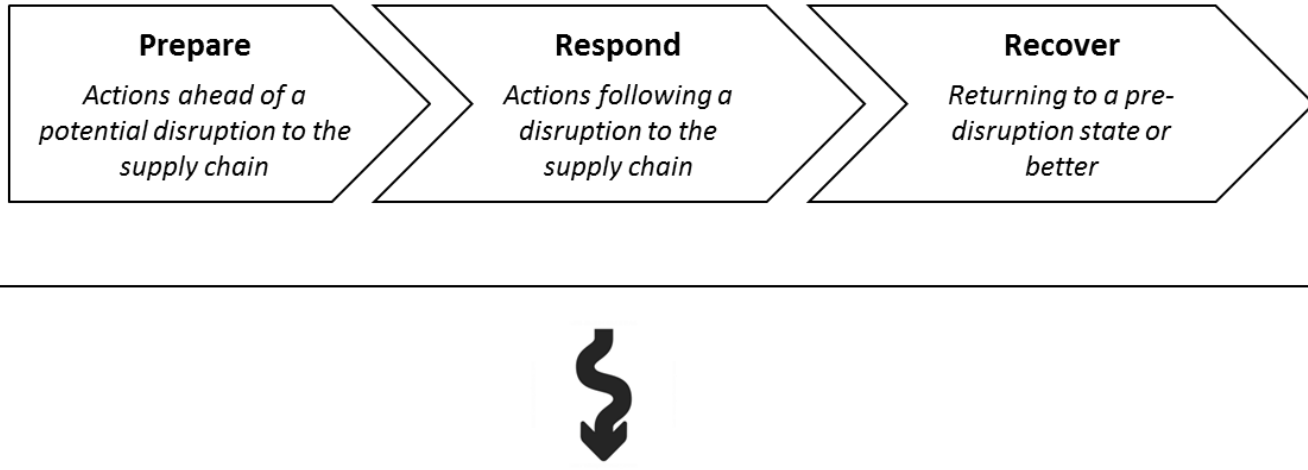

\section{Dynamic Capabilities Perspective}

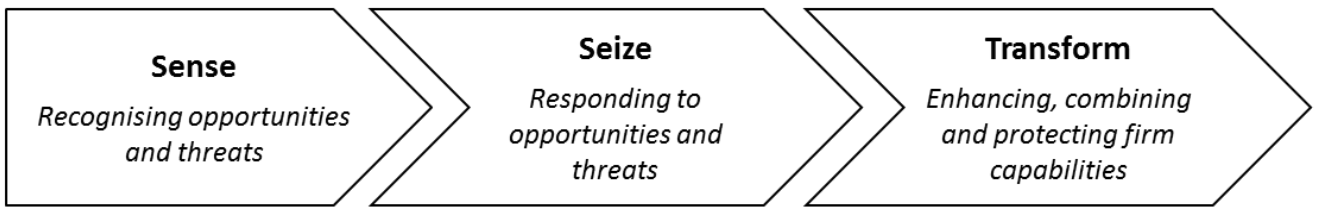

Figure 1: Research Model: Linking the Supply Chain Resilience and Dynamic Capability Perspectives

\section{Research Method}

To ensure that the research was carried out rigorously, four criteria around reliability and validity were applied, as summarised in Table 1 . The issues raised in this table are further discussed in sections 3.1 and 3.2 below, which respectively explain: the multi-case study research design and case selection; and the data collection and analysis. These four criteria are relevant to case study research (Gibbert et al., 2008; Yin, 2018) and have been adopted in exemplars of the use of the case study method (e.g. Reuter et al., 2010; Wilhelm et al., 2016). 
Table 1: Validity and Reliability Issues Addressed Throughout the Course of the Research ${ }^{\text {a }}$

\begin{tabular}{|c|c|c|c|c|}
\hline \multirow{2}{*}{$\begin{array}{l}\text { Reliability / } \\
\text { Validity Criterion }\end{array}$} & \multicolumn{4}{|c|}{ Research Phase } \\
\hline & Design & Case Selection & Data Gathering & Data Analysis \\
\hline $\begin{array}{l}\text { Reliability } \\
\text { (demonstrating that } \\
\text { the operations can be } \\
\text { repeated with the } \\
\text { same results) }\end{array}$ & $\begin{array}{l}\text { - Developed a case study protocol } \\
\text { - Development and use of case } \\
\text { study database }\end{array}$ & $\begin{array}{l}\text { - Clear involvement in 'local' food } \\
\text { supply chains, and all impacted } \\
\text { by Brexit }\end{array}$ & $\begin{array}{l}\text { Semi-structured interview } \\
\text { guidelines reported in the } \\
\text { interview protocol }\end{array}$ & $\begin{array}{l}\text { - Involvement of authors who } \\
\text { have not been in the field } \\
\text { gathering data } \\
\text { - Rigorous coding process }\end{array}$ \\
\hline $\begin{array}{l}\text { Internal Validity } \\
\text { (establishing a causal } \\
\text { relationship whereby } \\
\text { certain conditions are } \\
\text { believed to lead to } \\
\text { other conditions) }\end{array}$ & $\begin{array}{l}\text { Foundation of our research } \\
\text { model within the established } \\
\text { literature on SCRes and Dynamic } \\
\text { Capabilities }\end{array}$ & - $\mathrm{n} / \mathrm{a}$ & $\begin{array}{l}\text { - Multiple respondents } \\
\text { - Most knowledgeable, key } \\
\text { informants interviewed/ } \\
\text { included in the roundtable } \\
\text { discussions } \\
\text { - Interviews fully transcribed and } \\
\text { sent to interviewees for } \\
\text { checking }\end{array}$ & $\begin{array}{l}\text { - Pattern matching between the } \\
\text { cases } \\
\text { - Triangulation of data } \\
\text { - Discussion between authors to } \\
\text { agree coding }\end{array}$ \\
\hline $\begin{array}{l}\text { Construct Validity } \\
\text { (establishing correct } \\
\text { operational measures } \\
\text { for the concepts being } \\
\text { studied) }\end{array}$ & $\begin{array}{l}\text { - Adoption of questions linked to } \\
\text { extant SCRes and Dynamic } \\
\text { Capabilities literature }\end{array}$ & - $\mathrm{n} / \mathrm{a}$ & $\begin{array}{l}\text { - Multiple sources of information } \\
\text { - interviews, roundtable } \\
\text { discussions, observations and } \\
\text { secondary data }\end{array}$ & $\begin{array}{l}\text { Data triangulation between } \\
\text { interview data and roundtable } \\
\text { discussion data }\end{array}$ \\
\hline $\begin{array}{l}\text { External Validity } \\
\text { (establishing whether } \\
\text { and how a case study's } \\
\text { findings can be } \\
\text { generalised) }\end{array}$ & $\begin{array}{l}\text { - Adoption of Dynamic } \\
\text { Capabilities for 'Theory } \\
\text { Matching' (Zorzini et al., 2015) } \\
\text { - Comparative multiple case } \\
\text { studies } \\
\text { - Inclusion of NGOs } \\
\text { - Roundtable discussions to } \\
\text { validate/broaden the findings }\end{array}$ & $\begin{array}{l}\text { - Theoretical sampling using } \\
\text { replication logic - both literal } \\
\text { replication and theoretical } \\
\text { replication. }\end{array}$ & $\begin{array}{l}\text { - Gathering data on the case } \\
\text { contexts }\end{array}$ & $\begin{array}{l}\text { Pattern matching rather than } \\
\text { statistical projections used }\end{array}$ \\
\hline
\end{tabular}

aased on Yin (2018); Gibbert et al. (20008). 


\subsection{Research Design and Case Selection}

Given the explorative nature of the research, a multi-case study approach was adopted to enable in-depth investigation of the phenomenon of interest (Voss et al., 2016). The main aim was to develop theory around the concept of SCRes that would be explicitly relevant to disruption caused by constitutional change. However, given that existing literature around SCRes is growing, and a preliminary research model could be identified from that literature, then it was anticipated that the research would lead to an elaboration of the existing theory around SCRes rather than building theory from scratch. Thus the type of case study adopted can be described as 'theory elaboration' (Ketokivi \& Choi, 2014), which is also referred to as a 'gaps and holes' approach by Ridder (2017). In total, 14 case studies have been included: 3 NGOs (Non-Government Organisations); 3 farms; 4 processors; and 4 retailers. Hence, multiple tiers of food supply chains have been incorporated. Table 2 provides a list of these organisations and indicates the mnemonics used hereafter to refer to the data for the 18 individual interviewees. The cases were selected using theoretical replication sampling logic (Voss et al., 2016) to allow contrasting results to be identified but for predictable reasons (Yin, 2018; Voss et al., 2016). Thus, different tiers of the supply chain are included to provide both buyer and supplier perspectives; different product groups are included to allow for differences according to product type; and the variety of organisational sizes ranges from the family farm/farm shop through to a national supermarket chain. In addition, the three NGOs were selected to ensure a breadth of coverage of consumer issues as well as all farming types from horticulture/other crops through to dairy/eggs and livestock. Thus the research sought to ensure a breadth of understanding of the effect of Brexit on the local UK food industry. Finally, all of the organisations studied were known to have an interest in local food, albeit to varying degrees. For example, Retailers 1 and 2 both focus on primarily selling food produced in their local regions; whilst Retailer 3 has a reputation for stocking an above average percentage of local, artisan produce for the supermarket sector; and Retailer 4 stocks a wide portfolio of products, but this includes the strategic purchase and promotion of eggs from Local Farm 3 and sausages/ burgers from Local Processor 2. Thus there is an array of methods of operationalising the term 'local' covered in the cases studied including all produced and sold in the local region through to all produced and sold within the UK. 
Table 2: Interview and Workshop Participants

\begin{tabular}{|c|c|c|c|c|}
\hline \multicolumn{5}{|c|}{ Case Study Company Details and Associated Interviewee Mnemonics } \\
\hline Organisation & \multicolumn{3}{|c|}{ Products/ Services } & $\begin{array}{l}\text { Interviewee } \\
\text { Mnemonics }\end{array}$ \\
\hline NGO 1 & \multicolumn{3}{|c|}{ Farming Members Association } & NG1 \\
\hline NGO 2 & \multicolumn{3}{|c|}{ Farming Members Association } & NG2 \\
\hline NGO 3 & \multicolumn{3}{|c|}{ Food Policy Think Tank } & NG3 \\
\hline Farm 1 & \multicolumn{3}{|l|}{ Dairy Farm } & $\begin{array}{l}\text { F1-I1 } \\
\text { F1-I2 }\end{array}$ \\
\hline Farm 2 & \multicolumn{3}{|l|}{ Dairy and Genetics Farm } & $\mathrm{F} 2$ \\
\hline Farm 3 & \multicolumn{3}{|c|}{ Livestock farm (cattle, sheep \& chickens); and egg packing } & $\begin{array}{l}\text { F3-I1 } \\
\text { F3-I2 }\end{array}$ \\
\hline Processor 1 & \multicolumn{3}{|c|}{ Sandwiches, ready meals, vegetable boxes } & P1 \\
\hline Processor 2 & \multicolumn{3}{|c|}{ Sausage/ burger factory } & $\mathrm{P} 2$ \\
\hline Processor 3 & \multicolumn{3}{|l|}{ Bread producer } & P3 \\
\hline Processor 4 & \multicolumn{3}{|l|}{ Cake producer } & $\mathrm{P} 4$ \\
\hline Retailer 1 & \multicolumn{3}{|l|}{ Farm Shop } & $\mathrm{R} 1$ \\
\hline Retailer 2 & \multicolumn{3}{|l|}{ Innovative food boxes } & $\mathrm{R} 2$ \\
\hline Retailer 3 & \multicolumn{3}{|l|}{ Regional Supermarket } & $\begin{array}{l}\text { R3-I1 } \\
\text { R3-I2 } \\
\text { R3-I3 }\end{array}$ \\
\hline Retailer 4 & \multicolumn{3}{|l|}{ National Supermarket } & R4 \\
\hline \multicolumn{4}{|c|}{ Total participants: } & 18 \\
\hline \multicolumn{5}{|c|}{ Workshop Participants and Associated Workshop Mnemonics } \\
\hline \multicolumn{2}{|c|}{ Organisational types represented } & Workshop 1 (W1) & Worksl & op 2 (W2) \\
\hline \multicolumn{2}{|c|}{ Farmer } & 4 & & 1 \\
\hline \multicolumn{2}{|l|}{ Processor } & 1 & & 2 \\
\hline \multicolumn{2}{|l|}{ Retailer } & 2 & & 2 \\
\hline \multicolumn{2}{|l|}{ NGO } & 3 & & 4 \\
\hline \multicolumn{2}{|r|}{ Total participants: } & 10 & & 9 \\
\hline
\end{tabular}

\subsection{Data Collection and Analysis}

Data collection began after the Brexit vote in June 2016, taking place between November 2016 and September 2017. There were two stages of data collection. First, interviews with the 18 representatives from the 14 cases listed in Table 2 were carried out. Second, to validate and broaden the findings, all interviewees (and other non-interviewees) were invited to one of two roundtable discussions. Ten participants attended the first of these workshops, 7 of whom were interviewees. As no new issues were identified, this workshop was able to validate and triangulate the original findings from the interviews. At the second workshop, there were nine participants, none of whom had taken part in the interviews, and therefore this workshop sought to broaden the findings. In the event no new issues were raised so again this workshop aided in the triangulation of the data leading to confidence that the research had reached data saturation. The organisational types represented at the two roundtable discussions are also given in Table 2. As the Chatham House rule was agreed, evidence from the workshops is not attributed to individuals but is anonymously referred to by the mnemonics $\mathrm{W} 1$ and $\mathrm{W} 2$ for workshops 1 and 2, respectively. 
The initial interviews focused on three main categories of questions - each of which was investigated both for the individual organisation and its wider supply chain. First, the nature of the current business model and supply chain relationships was explored. This data allowed for the analysis of the extant vulnerabilities and strengths; enabled historical analysis of SCRes (as prior system shocks along with system responses were described by respondents); and provided an understanding of the contextual advantages and disadvantages of EU membership. Second, the processes surrounding the Brexit vote were examined to explore what information was available prior to the vote as relevant to the organisation/supply chain; and to determine any immediate effects of the vote process itself or the outcome of the vote. Third, the potential impact of Brexit, i.e. the future point in time when the UK leaves the EU, was discussed with each interviewee.

A case study protocol was used to ensure consistent coverage of the interview questions and to ensure that due attention was given to research ethics procedures. The interviews were semi-structured, allowing the interviewee to provide additional information as appropriate and to enable freedom of expression. For the majority of the cases, data triangulation was provided either by collecting data from multiple interviewees, observation, or through additional documentary evidence. To ensure reliability and internal validity of the data, it was all recorded, fully transcribed and sent to the interviewees for checking. Data analysis was carried out by coding the data, using both open coding and constructs from the dynamic capabilities literature. Findings from the case study analysis were presented at the two roundtable discussions - thus a key objective for these events was to validate and discuss the results of the study thus far. In addition, each participant of the roundtable discussion was asked to speak for five minutes on the expected impact of Brexit on their organisation/ area of expertise, including how they were planning to grasp opportunities as well as respond to threats. Thus the roundtable discussions also enabled the collection of additional data to triangulate the findings, although no new issues were raised. Overall, we iterated between the data collection and data analysis phases of the research until there was confidence amongst the research team that sufficient data had been collected to answer the research question.

\section{Findings}

Our findings suggest that a significant stage in building SCRes during constitutional change involves developing a deep understanding of the potential disruption - the stage labelled sensing using the dynamic capabilities theoretical lens adopted in this paper. Thus this section commences below with a discussion of how organisations are sensing the challenges/threats and opportunities surrounding Brexit in sections 4.1 and 4.2, respectively. This is followed by a description of how some of the organisations studied are 'seizing' opportunities and beginning the process of 'transforming' in Section 4.3. All three stages together are argued to be important parts of the process of building SCRes. Yet some firms have claimed to be reliant on extant SCRes, rather than needing to seize opportunities or transform their businesses at this point in time. Table 3 summarises key constructs from the empirical evidence on which the discussion in the three subsections below is built. 
Table 3: Summary of Key Empirical Evidence

\section{(a) Evidence of Threats/Challenges Surrounding Brexit}

\section{Threat/ Challenge}

Worse replacement of

the CAP (Common

Agricultural Policy) e.g.

in terms of regulation

and farm subsidy

Uncertainty leading,

for example, to a lack

of investment

confidence

Poorer international

trade agreements

\section{Labour shortages}

especially in

horticulture and the

abbattoirs

\section{Food price inflation}

e.g. due to higher

labour costs or lower

farm subsidy

\section{Fewer family farms}

due to efficiency drives

\section{Sample Quotes from the Evidence}

"Then in terms of the subsidy, the likelihood is that in the next 2 to 3 years it'll dwindle or even disappear" F2

"... a lot of the regulations for food safety and quality could be compromised if it means that the UK doesn't create its own standards that are in line currently with Europe. "R3-12

"we do need to head off a danger, which is that we go and ditch some of our environmental credentials under the pressure to go and do deals and get trade going and all the rest of it. So we need to head that off. "W1

"I think that the uncertainty and lack of decision-making would be right at the top for me. It's the unknown, there is no will to reinvest ... we could be 2 to 3 years away from any real decision-making, you know anything to hang your hat on. So for me the instability and the uncertainty is top of the list for me." F2

"The majority of horticultural businesses I'm speaking to are in a bit of a wait and see at this moment in time ... they are thinking, 'If it's going to cost me $£ 200,000$ to put this machine in, it's going to replace 20 workers, let's just wait and see before making that investment as well.'"W2

"It will depend on what happens when our government goes to the EU on mass for trade deals, they may say that actually they want to retain this part of our industry, and we're not going to put any tariffs on, but farming may be the industry that gets sacrificed, the sacrificial lamb. It depends what they are going to negotiate on ... I think farming will be net losers". F2

"One of the biggest concerns after the vote was staff ...Initially the Polish lads, there was a great deal of concern." P4

"The two [European] lads, one lad on the van is a fully qualified paramedic and the other lad has just finished a full career in the army a paramedic, battlefield medic. Just amazingly talented individuals, amazing intelligent individuals ... They bring that into whatever job they're doing and they do that job really, really well. That is going to be such an enormous loss if that's taken away from us. Enormous loss. I think it's greatly undervalued." P3

"If the food industry in the UK fell on its face, which it would if it didn't have that access to that labour or non-EU labour, that would lead to obviously considerable food price inflation." W1

"If one third, that's the number touted about, one third of farm income is from EU subsidies then in essence farm prices should be 50\% higher if we are paying the true price and that would be reflected ultimately through price at the tills ... "P1

"...there is the trend towards ... only big businesses currently surviving the kind of environment. So, you get a sense that ... there will be a continual consolidation and possibly an acceleration because of the uncertainty and bureaucratic barriers to trade with Europe outside of the EU." NGO3

"it's all very well for the government to sit there and say, 'Okay, we don't need to protect the family farm,' but unless they manage
P1, P2-I1, R3-I1,

R3-I2, R4,

NGO1, NGO2,

$\mathrm{NGO}, \mathrm{W} 1$

$F 1-I 1, F 2, P 1$

P2-I1, R2, R4,

NGO1, NGO2,

NGO3, W1, W2

F1-I1, F2, P1,

P2-I1, R3-12, R3

I3, R4, NGO1,

$\mathrm{NGO} 2, \mathrm{~W} 1$

F1-I2, F3-I1, P3,

P4, R1, R2, R3-

I2, NGO1,

$\mathrm{NGO} 2, \mathrm{NGO}_{3}$

W1

F1-I1, F2, P1,

P2-I1, P3, P4,

R3-12, W1, W2

F1-I2, F2, NGO3,

W2 


\begin{tabular}{|c|c|c|}
\hline & that as an extremely gradual process you'll have a lot of social crisis in rural areas ... " W2 & \\
\hline $\begin{array}{l}\text { Lack of voice for the } \\
\text { farming community }\end{array}$ & $\begin{array}{l}\text { "There is very few of us that actually get this money [CAP] and we can't pull that many votes". F1-I2 } \\
\text { "The government are not going to be sitting around the table talking to groups of farmers for any length of time. They're going to be } \\
\text { talking to the likes of Waitrose, the head of Aldi and Sainsbury's and so on, to ask what do we need to do to make sure that your } \\
\text { shelves are full. They will want to keep a lid on food price inflation, end of story". F2 }\end{array}$ & $\begin{array}{l}\text { F1-I1, F1-I2, F2, } \\
\text { NGO3 }\end{array}$ \\
\hline $\begin{array}{l}\text { Currency effects, } \\
\text { leading to more } \\
\text { expensive imports }\end{array}$ & $\begin{array}{l}\text { "I think the weakening of our currency that we have seen since Brexit will have a benefit to our businesses in the short term but I think } \\
\text { the consequences of that in the medium and long term could be very challenging" F1-I2 } \\
\text { "Exchange rates, for instance. If anybody here ever buys oven chips... anybody? No, we're all far too middle-class to buy oven chips. } \\
\text { Okay, one or two, thank you. You cannot find an own-label oven chip in the UK that's not made in Belgium. So your oven chips, which } \\
\text { are about the lowest common denominator you can find in terms of food value are... [more expensive]... The reason the chips are } \\
\text { manufactured in Belgium is not because we prefer Belgian potatoes to British potatoes, it's because there's been massive capital } \\
\text { investment in very efficiently converting potatoes into chips. ... Once you've got the money in the system, it's really hard to change } \\
\text { course, and there are relatively high barriers to entry... So there's a currency challenge." W1 }\end{array}$ & $\begin{array}{l}\text { F1-I2, P4, NGO2, } \\
\text { W1 }\end{array}$ \\
\hline \multicolumn{3}{|c|}{ (b) Evidence of Opportunities Surrounding Brexit } \\
\hline Opportunity & Sample Quotes from the Evidence & Sources \\
\hline $\begin{array}{l}\text { A new competitive } \\
\text { landscape that } \\
\text { potentially favours } \\
\text { local food }\end{array}$ & $\begin{array}{l}\text { "In terms of the food from abroad that we compete with, it will become more expensive to the consumer so that gives us more } \\
\text { opportunity however our input will be on the same scale more expensive..." F1-I2 } \\
\text { "I think we'll be okay because I think we're a British company and we're really based on localism. Yes, I think for anybody with a more } \\
\text { European supply chain I think it will be really difficult, I really do." P2-I1 }\end{array}$ & $\begin{array}{l}\text { F1-I2, P2-I1, P2- } \\
\text { I2, P4, R2, R3-I1, } \\
\text { R3-I2, R3-I3, R4 } \\
\text { NGO1, NGO2, } \\
\text { NGO3, W1 }\end{array}$ \\
\hline $\begin{array}{l}\text { Better CAP } \\
\text { replacement e.g. with } \\
\text { more effective } \\
\text { subsidies. }\end{array}$ & $\begin{array}{l}\text { "So it might be that a funding scheme going forward is where a farmer's decided to look at his costs and go somewhere where he's } \\
\text { helping himself with cost efficiency, that triggers funding for that farm. ... it's the better farmers that need to be rewarded so it } \\
\text { pushes the other ones to get better and make a better job of what they're doing ..." F3-I1 } \\
\text { "one thing that governments will look at, which is important as well, is the tourism and tourism and agriculture. So if those farmers } \\
\text { are getting a bigger-ish payment linked to looking after that environment in a way that is encouraging for the tourism, that's all very, } \\
\text { very important, because tourists are eating food there and all the rest of it. So it's about balance." F3-l1 }\end{array}$ & $\begin{array}{l}\text { F2, F3-I1, F3-I2, } \\
\text { P1, R3-I1, } \\
\text { NGO1, NGO2, } \\
\text { NGO3, W1, W2 }\end{array}$ \\
\hline $\begin{array}{l}\text { More effective supply } \\
\text { chain business models }\end{array}$ & $\begin{array}{l}\text { "There are plenty of farms that could adjust their lambing times, or those sheep that are seasonal lambers or performers, I guess, you } \\
\text { could extend it. You could extend the season, there's no doubt about that, but you could also make more of older-season lamb and } \\
\text { that's something that I think we've really failed in. "NGO2 } \\
\text { "we're not a charity, but it is making us think differently about where we can offer support versus where we do also need to make } \\
\text { money, and I think the landscape has changed. I mean, I've seen what's happened in the last five months have a dramatic impact on } \\
\text { certain relationships that we've got in the business and we are having to think differently about the way we work with suppliers." R3- }\end{array}$ & $\begin{array}{l}\text { F1-I2, F2, F3-I1, } \\
\text { R3-I2, NGO1, } \\
\text { NGO2 }\end{array}$ \\
\hline
\end{tabular}




\begin{tabular}{|c|c|c|}
\hline & 12 & \\
\hline $\begin{array}{l}\text { Increased export } \\
\text { opportunities }\end{array}$ & $\begin{array}{l}\text { "What might happen is we look to a degree of internationalisation (and I'm not going to define how that might appear) but we might } \\
\text { look to a degree of internationalisation that we haven't done historically ..." } P 1 \\
\text { "X mentioned the halal market. There are about } 12 \text { million Muslims in France and Germany and that is a massive export market for } \\
\text { us. That market will not go away after Brexit, it will be there. The question is at what cost will we access the market? "W1 }\end{array}$ & $\begin{array}{l}\text { F1-12, P1, P2-12, } \\
\text { R2, R3-I2, } \\
\text { NGO1, NGO3, } \\
\text { W1 }\end{array}$ \\
\hline $\begin{array}{l}\text { Improved } \\
\text { international trade } \\
\text { agreements }\end{array}$ & $\begin{array}{l}\text { "I think even if we built our domestic market up here in the UK, there are still a lot of products within our sheep that we don't } \\
\text { consume here, and yet they do in other populations across the world. The more we get eaten, the less we have to pay to get disposed, } \\
\text { so the more we can sell. So the opening up of the Chinese market to sell the fifth quarter-type products, bits and pieces that we } \\
\text { wouldn't dream of eating here." NGO2 } \\
\text { "[politicians have] been talking about food becoming cheaper post-Brexit. That was something that was spoken about by the Brexit } \\
\text { campaign. Largely that argument hinges on trade, doing free trade deals with non-EU countries such as, let's say India, let's say New } \\
\text { Zealand, let's say Argentina. "W1 }\end{array}$ & $\begin{array}{l}\text { P2-I1, NGO1, } \\
\text { NGO2, NGO3, } \\
\text { W1 }\end{array}$ \\
\hline \multicolumn{3}{|c|}{ (c) Evidence of Extant Resilience Attributes } \\
\hline Resilience Attribute & Sample Quotes from the Evidence & Sources \\
\hline $\begin{array}{l}\text { Assets e.g. land, } \\
\text { buildings, production } \\
\text { capacity etc }\end{array}$ & $\begin{array}{l}\text { "And land values have traditionally always been resilient in my career but, like I said earlier, that doesn't mean to say they always will } \\
\text { be... That could affect the value of our assets." F1-I2 } \\
\text { "There's no shortage of people that have invested off the farms too, so they've bought properties and they've become landlords, } \\
\text { they're letting residential properties. You see that in clusters. I'm not sure whether you'd see it here, but certainly Aberystwyth you } \\
\text { see it a lot. It's a university town and a lot of the farmers have bought up houses in Aberystwyth and let them to students. "NGO2 }\end{array}$ & $\begin{array}{l}\text { F1-I2, F3- I1, P2- } \\
\text { I1, P3, P4, NGO2 }\end{array}$ \\
\hline $\begin{array}{l}\text { Government support } \\
\text { e.g.for farming, due to } \\
\text { food security needs, } \\
\text { environmental } \\
\text { stewardship needs and } \\
\text { links to tourism. }\end{array}$ & $\begin{array}{l}\text { "I think in the future the sort of things that we probably get paid for cannot be classed as subsidy, we'll be paid for providing a service, } \\
\text { environmental announcements or public good, etc., "W1 } \\
\text { "you get the sense that there could be opportunity for the whole agricultural sector and horticultural sector for - ... - discussions } \\
\text { around national resilience and national food security and protecting UK industry, etc., etc." NGO3 }\end{array}$ & $\begin{array}{l}\text { F3-I1, F3-I2, } \\
\text { NGO3, W1 }\end{array}$ \\
\hline $\begin{array}{l}\text { Entrepreneurial spirit } \\
\text { e.g. to develop new } \\
\text { suppliers with 'quirky' } \\
\text { products }\end{array}$ & $\begin{array}{l}\text { "[R3] hosts quarterly what's called a Meet the Buyer day and the purpose of that is to allow suppliers who have submitted ideas in } \\
\text { through a.. Meet The Buyer website portal, things that they believe we could do so much better than anybody else, and the kind of } \\
\text { quirky ideas that some of them have got we'll truly value. Those that are successful, we invite the buyers in to meet the buyer and } \\
\text { showcase their product, so it's a really interesting day because we'll see certain things that we've never seen on the market before" } \\
\text { R3-I2 } \\
\text { "Not only have we been first to market, we've also been almost like a test bed or a launch pad for companies that have subsequently } \\
\text { grown to be suppliers to the whole of the UK" R3-I3 }\end{array}$ & $\begin{array}{l}\text { F1-I1, F1-I2, F2, } \\
\text { F3-I1, R1, R3-I1, } \\
\text { R3-I2, R3-I3, W1 }\end{array}$ \\
\hline
\end{tabular}




\begin{tabular}{|c|c|c|}
\hline $\begin{array}{l}\text { Risk assessment and } \\
\text { risk taking e.g. when } \\
\text { entering new markets } \\
\text { or assessing the } \\
\text { potential impact of } \\
\text { Brexit }\end{array}$ & $\begin{array}{l}\text { "now [F1's] challenge, and this is what will make or break him in terms of the beginning of his career, is to now turn round what } \\
\text { happened in the last month and make a new market on the back of that, where we spread our risk across a number of different } \\
\text { people. And l'll be fascinated to see how that goes." F1-I2 } \\
\text { "It's [Brexit is] a watching brief and it's taking advice from people who are better placed than us. So it's people within the financial } \\
\text { community, banking, professional services organisations. It will be interesting to see, we have a global professional services company } \\
\text { doing some work for us looking at risk. "P1 }\end{array}$ & $\begin{array}{l}\text { F1-I2, F3-I2, P1, } \\
\text { P3, R1, R4, } \\
\text { NGO2 }\end{array}$ \\
\hline $\begin{array}{l}\text { Supply chain } \\
\text { relationships e.g. to } \\
\text { communicate } \\
\text { effectively to } \\
\text { consumers and to } \\
\text { ensure appropriate } \\
\text { pricing for milk and } \\
\text { lamb }\end{array}$ & $\begin{array}{l}\text { "I think one of the pleasurable things about our business is relaying that to our customers and being able to say "look our prices are } \\
\text { like this because this is what we do. This is where our ingredients come from, and this is what we do, this is how we handle it and it is } \\
\text { different". It is a pleasure relaying that and telling the story. It helps businesses like ours survive really." P4 } \\
\text { "Very much what we try and do is deal directly with first-tier suppliers. Our objective is always to cut out the middleman because of } \\
\text { the size of our business and go straight to source. We feel that it's more transparent, we feel that it's about maintaining the } \\
\text { relationship with the first tier, so that we can work in partnership with them ... we very much try and work with local suppliers where } \\
\text { there's a win-win solution for both."" R3-I2 }\end{array}$ & $\begin{array}{l}\text { F1-I1, F2, P1, } \\
\text { P2-I1, P4, R3-I1, } \\
\text { R3-I2, R3-I3, R4, } \\
\text { NGO1, NGO2, } \\
\text { NGO3, } \\
\text { W1 }\end{array}$ \\
\hline $\begin{array}{l}\text { Diversification e.g. into } \\
\text { other businesses, } \\
\text { additional supply chain } \\
\text { tiers, or new crops } \\
\text { following market } \\
\text { demand }\end{array}$ & $\begin{array}{l}\text { "the development of [the farm shop and factory unit complex]... got me out of the farmyard with another project of diversification to } \\
\text { take the business forward" F3-I1 } \\
\text { "We have a big range of Jewish foods in the counter, because the population in the ... area does have more Jewish customers. We've } \\
\text { not done that before in other regions, but where there's a dense population of certain cultural or religious values, then we will put } \\
\text { more products of that type" R3-I2 } \\
\text { "So, we had Charollais sheep and Charolais cattle. Those breeds were imported from Europe because of the desire at that time for } \\
\text { lean meat. Everybody was talking about lean diets, less fat and that" F3-I1 } \\
\text { "I think arable will survive because equally if you've got arable land it will lend itself to other sorts of things so you could do other } \\
\text { sorts of things potentially, grow other crops you know just for the market. "NGO1 }\end{array}$ & $\begin{array}{l}\text { F1-I1, F2, F3-I1, } \\
\text { P2-I1, R3-I2, R1, } \\
\text { R3-I3, NGO1, } \\
\text { NGO2, NGO3, } \\
\text { W1,W2 }\end{array}$ \\
\hline
\end{tabular}




\subsection{Sensing Challenges and Threats Surrounding Brexit}

The main challenges/threats identified from the cases can be summarised as follows:

1. A (worse) replacement of the CAP (Common Agricultural Policy) and the associated subsidies for farmers;

2. Uncertainty leading, for example, to a lack of investment confidence;

3. Poorer international trade agreements;

4. Labour shortages;

5. Food price inflation;

6. Fewer family farms;

7. A lack of voice for the farming community;

8. Currency effects.

The evidence for each of these challenges/threats is summarised in part (a) of Table 3. As discussed below, these factors all have the potential to have a significant impact on: supply chain prices; supply chain social and environmental sustainability; and therefore on local food supply and its resilience.

In terms of the potential impact on supply chain prices, this may be affected by a lower level of CAP subsidy given that effectively this subsidy reduces the price of food at the point of purchase by the consumer. As stated by interviewee F1-I1, "you would think generally that they [the subsidies] find their way to the consumer's pocket ... It affects the price of the food that the processor pays and the retailer pays and ultimately it is knocked off the end price of the food ... the consumer product. I think that's what the government has to think about rather than whether a specific farmer ... is gonna get that $x$ amount of cash in his pocket, it's the overall price of food." Thus, if subsidies are lower, it follows that the price of food may increase if the affected local farms continue to supply that food. This effect will vary according to farming sector, as argued by NGO1: "The sector that's most exposed is the livestock sector. That's the one that's always received the highest level of subsidy. If you take the subsidy out of those systems, virtually none of them return any sort of profit. And the sector that is massively dependant is the upland livestock sector. If you look at their figures in terms of income, in some circumstances it may be that $50-60 \%$ of their income is derived from subsidy, particularly if you've got a big fell farm with an environmental scheme, and a big basic payment scheme; so, the one sector that is probably most at risk in terms of Brexit [...] in terms of change of support is probably the upland sheep sector." Opinions varied in terms of the risks of subsidies being changed with NGO2 recognising competing demands on government budgets: "it's going to be a big battle, holding onto that budget for agricultural and rural development, I've got no doubt about that. I do think a lot of things that are coming out of the National Health Service [NHS] at the moment are preparing the ground, additional money needed in the NHS..."; whilst NGO3 stated: "you get a sense there will be some kind of subsidies involved in a post-Brexit food farming strategy ... you kind of get a sense that it will probably be close to status quo; so an emphasis on direct subsidies based on land area, so the effective under-subsidisation of horticulture which uses less land ... So, you get a sense that probably in terms of support, etc., it's probably business as usual." Thus, whilst there was not a consensus on the likely levels of future support post Brexit, it is important to understand the potential impact of 
changes on future food prices. In addition, supply chain prices have already risen due to currency effects that have made the price of imported food more expensive, and there is ongoing uncertainty regarding the future effect of the Brexit decision on exchange rates.

If food price inflation does occur, then the market may respond in a number of ways and the interviewees expressed concern about the detrimental effect of some of these potential responses on social and/or environmental sustainability in the supply chain. In particular, several interviewees stressed that attempts to reduce food prices through greater farm efficiency have the potential to reduce the number of smaller family-run farms, which are at the heart of many rural communities. For example, F2 stated: "... there is the danger around Brexit combined with the financial crisis, with global over supply, I think there is a perfect storm right now. There is a global will to keep food prices really low ... The combined effect of the two things is the reason that many dairy farmers are likely to be unable to survive over the next two to three years ... $3 \%$ of the dairy farms in the USA produce $50 \%$ of the milk, and that model is coming here ... There will be more commercially run farms, and less of the family units. This will affect all sectors of farming". The threat was argued to be significant by F1-I1, F2 and NGO3, given a perceived lack of voice for the farming community compared with other sectors. Alternatively, more food could be imported, which may be cheaper (irrespective of fluctuating exchange rates) due to lower standards of environmental and/ or social sustainability. As stated by R3-I2: "the effect of coming out of Europe [could be] opening up international trade where certain goods may become cheaper, but a lot of the regulations for food safety and quality could be compromised if it means that the UK doesn't create its own standards that are in line currently with Europe". This could then threaten the overall supply of food to the UK if it becomes more dependent on global supply chains and their vulnerability to transportation risks/ natural disasters.

SCRes will also be impacted by the availability of European migrant workers, which was argued to be particularly important to: the horticultural sector (NGO3); to the processing tier of the supply chain, such as large abattoirs (NGO2); and also to Processor 3, which is a small artisan baker. Moreover, many of the farming sectors rely on international trade agreements both within the EU and further afield for their export markets, thereby supplementing the income achievable in the UK. Thus the threat of poorer trade agreements is also likely to impact the viability of UK farming. As stated by NGO1: "So, if we did have a situation like the Doomsday scenario, which is no market access to Europe plus no support, I think you would see an absolute devastation". Thus many of the interviewees were keen to stress the perceived threats and challenges surrounding Brexit. However, there were also a number of opportunities created by Brexit that were identified, as discussed below.

\subsection{Sensing Opportunities Surrounding Brexit}

The opportunities identified by the interviewees can be categorised as follows:

1. A new competitive landscape that potentially favours local food;

2. Better CAP replacement with more effective subsidies;

3. More effective supply chain business models;

4. Increased export opportunities;

5. Improved international trade agreements. 
The evidence for each of these opportunities is presented in part (b) of Table 3. Opportunity \#2 and \#5 are the opposite of two of the perceived threats and challenges from part (a) of Table 3 (Challenge \#1 and \#3), highlighting the sense of uncertainty surrounding the current constitutional context, and recognising the opportunity for organisations to lobby the government for positive changes. However, there are also opportunities that are within the control of the supply chain organisations, as discussed below.

The first such opportunity is to increase sales if the new constitutional context favours local food. This could be due to a "kind of insular turn in the country" (NGO3), leading to greater customer demand for local food, as argued by P2-I1: "[national supermarket chain X] ... they're really trying to push local sourcing now ... I do think that probably will protect us from Brexit turbulence", and corroborated by a report recently published by the supermarket chain Morrison's outlining a policy to buy more local produce (see Benton et al., 2017). Thus, as further argued by NGO3: "you get the sense that there could be opportunity for the whole agricultural sector and horticultural sector for ... discussions around national resilience and national food security and protecting UK industry". A second reason for this potential increase in local food demand is related to the costs of imported goods, as argued by R3-13: "There's a possibility that increasing costs of imported goods will drive sourcing to UKproduced [goods] a bit more." However, the same interviewee also stated that: "We're almost at the limits now [on local sourcing] in my personal opinion because our sourcing policy, whether it's been written down or not written down, is that we'll try our best to source locally; but if it's uncompetitive and the quality isn't there, or the safety isn't there, we're not going to source it." Therefore, whilst this opportunity may be available for increasing the production of local food, this may be constrained by the capabilities of local producers. Thus this first opportunity is also linked to the opportunity to improve business models, as the two aspects may need to go hand-in-hand if Brexit-related opportunities are to be realised.

In terms of opportunities for improved business models, these were primarily targeted at the farming sector, with a particular emphasis on the need for better volatility management and to ensure profitable farming that is either less reliant on government subsidy or incentivised by a better replacement of the CAP subsidy. As stated by F3-I1: "So it might be that a funding scheme going forward is where a farmer has decided to look at his costs and go somewhere where he's helping himself with cost efficiency, that triggers funding for that farm." Better volatility management is needed given that prices can rise and fall on the commodity markets, as argued by NGO1: "So what you need to be is as efficient as you possibly can and understand that the price isn't only going to go up. They [prices] are going to come down as well ... what you need to do in that sort of scenario is get the cost of production down as low as you possibly can. ... When the price goes up to ... don't go and buy three new tractors. ... Use that money to see you through the low. So it really depends I would have said on where individual businesses are in terms of knowing the cost of production, understanding the market they are in, as to how likely they are to survive when $C A P$ changes". It can therefore be concluded that organisations are sensing both opportunities and threats surrounding Brexit. 


\subsection{Seizing Opportunities and Beginning to Transform}

Having 'sensed' the threats and opportunities surrounding Brexit, the findings also suggest that, at the farming tier, organisations are beginning to 'seize' opportunities to strengthen their businesses; and are 'transforming' accordingly. For example, Farm 1, which had previously supplied milk to the local liquid milk market only is currently exploring opportunities to sell to the more profitable London coffee milk market, seeking several customers so as to spread the risk. Thus their aim to: "make a new market ... where we spread our risk across a number of different people [customers or markets]" (F1-I2). Others have already become more resilient through responding to prior shocks felt in the farming sector (e.g. foot and mouth disease, salmonella scandals, etc.), and have thus diversified to become less reliant on the CAP subsidy. For example, Farm 3 changed the breeds of livestock kept to produce more lean cuts and expanded into the egg packing business as the demand for free range eggs grew. Thus, they have made previous timely and market focused transformations. Nonetheless, this organisation is far from complacent and is one of the most proactive in aiming to influence future agricultural policy. Thus, in this case, they are 'seizing' the opportunity to influence government rather than to transform their business, and this may be an equally important dynamic capability in the Brexit context.

In contrast, at the processor and retailer tiers, the interviewees commonly expressed a 'watching brief' attitude, and thus these tiers can be described as being in the early stages of 'sensing' (rather than 'seizing') the impact of this constitutional change. For example, R4 stated: "Part of the challenge is these types of conversations are you're talking three to five years hence. Retail thinks six months hence tops [at most]. There's a real disconnect in the timescales. What keeps me in a job is trying to work our way through them but it's a bit Darwinian. It's nothing to do with size and strength, it's just how quickly we can adapt". Thus, concern at this tier is lower on the basis of confidence that they will be able to continue to source food and can adapt quickly to new suppliers as required, even if those suppliers are not local to the UK. Thus these tiers claim to be reliant on extant SCRes, as summarised in part (c) of Table 3.

\section{Discussion: Building SCRes during a Period of Constitutional Change}

The findings of this study lead to three contributions to the literature by:

- Providing empirical evidence of the importance of proactive strategies to build SCRes during periods of constitutional change;

- Providing empirical evidence of the need for firms to anticipate the likely impact of constitutional change - leading to innovation at the individual firm level, whilst the supply chain as a whole adapts to more sustainable pricing strategies;

- Describing the characteristics of a disruption caused by constitutional change and how this type of disruption affects the dynamic capabilities needed to build SCRes.

Each of these contributions is discussed in turn below, leading to a proposition that adds to the extant theory on SCRes. Overall, it is argued that dynamic capabilities play an important role in influencing change in government policy and/or transforming businesses within the supply chain, along with their supply chain relationships, in order to build SCRes, as depicted in Figure 2. 
Figure 2: Building Resilience to Constitutional Change

\section{Constitutional Change}

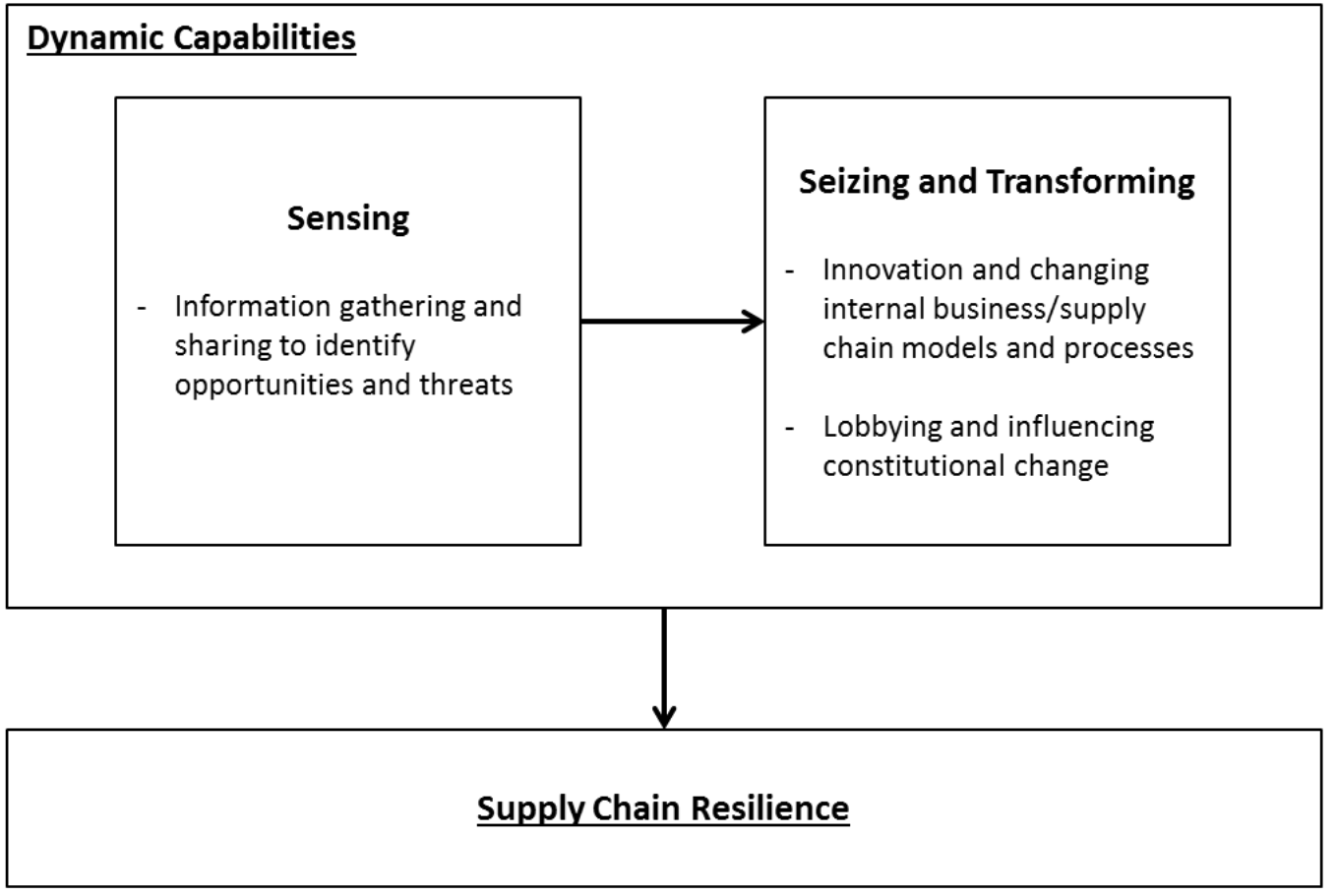

First, the findings suggest that an effective proactive strategy is to collaborate both horizontally and vertically to become involved in influencing the future shape of the constitution, which in this study includes: the replacement for the CAP subsidy to support economic, environmental, and social sustainability; international trade agreements that will impact access to export markets; and regulations to enable migrant workers to continue to be employed in key sectors such as horticulture and abattoirs. In order to do this, organisations first need to work together to understand the likely impact of the constitutional change at the supply chain level, thereby enabling the development of manifestos relevant to whole supply chains. To the best of our knowledge, the dynamic capabilities literature (e.g. Teece et al., 1997; Eisenhardt \& Martin, 2000; Teece, 2007) has not previously emphasised the importance of actors at the same tier of the supply chain working together to sense and adapt to changes in the external environment. This approach is partly explained by the uncertainty surrounding Brexit and has been facilitated by access to networks, NGOs and trade unions. By coming together, firms are sharing information and farmers in particular can have a louder voice collectively in terms of communicating their concerns to government. These findings build on prior resilience theory that postulates the need to accurately anticipate disruptions (e.g. Stone \& Rahimifard, 2018) and to set up proactive strategies as a means of building resilience (e.g. Tukamuhabwa et al., 2017). Thus the first proposition resulting from this study is: 
Proposition 1: Horizontal and vertical collaboration between supply chain actors are important proactive strategies for building resilience during periods of constitutional change in order to:

(i) sense the effect of potential changes to the constitution and accurately anticipate the potential impact of disruptions in terms of economic, environmental, and social sustainability; and

(ii) seize the opportunity to effectively lobby government and influence the constitutional change.

Second, the findings provide empirical evidence of both individual organisations and supply chains seizing opportunities to reconfigure their operations so that they become less reliant on government subsidy, thereby strengthening their position in the local food supply chain. This can, for example, involve farmers innovating their businesses by diversifying their income streams or it can involve whole supply chains rethinking pricing strategies to ensure that all parties are operating in a profitable and sustainable manner. In both cases, whether the change is at the firm level, or the supply chain level, there will be a need for the likely impact of the disruption to be accurately anticipated. This further expands on the discussion of Stone \& Rahimifard (2018), who described the need to accurately anticipate the disruption itself - in the case of constitutional change, the disruption is inevitable, but it is the impact of the disruption that needs to be accurately anticipated so that appropriate strategies for innovation can be adopted. This leads to a second proposition, which is divided into two parts:

Proposition 2a: Firms with dynamic capabilities to innovate in anticipation of the likely impacts of constitutional change will be able to build resilience to enhance their competitive position despite the inherent uncertainty associated with this type of disruption.

Proposition 2b: Supply chains with dynamic capabilities to adapt to more sustainable pricing strategies in anticipation of the likely impacts of constitutional change will be able to build SCRes to enhance their competitive position despite the inherent uncertainty associated with this type of disruption.

Third, as the resilience of supply chains to constitutional change is studied here for the first time, it has become apparent that there are clear differences in the characteristics of constitutional change when compared to other threats and disruptions to supply chains, including devastating earthquakes, fuel crises, political turmoil, diseases, terrorism, and hurricanes (e.g. Mandal, 2012; Scholten et al., 2014). Firms might prepare for a disruption caused by a tsunami or terrorist attack by having clear plans and procedures in place to mitigate the consequences; but such a disruption is likely to happen at short or no notice, or it might not occur at all. Similarly, a firm may plan for a small scale supply disruption, as featured in Tukamuhabwa et al. (2017), such as a late or cancelled delivery through redundancy and flexibility, including by holding small buffer stocks or having multiple or alternative sources of supply. But constitutional change is different in that firms (at the farming tier of the food supply chain at least) began planning two years ahead of the disruption, which gives them time to anticipate and change their practices. The process of 
building resilience to constitutional change is therefore somewhat different to building resilience to other threats. In particular, there is a long time horizon involved in the disruption; there is a high certainty of disruption; the event is known and deliberate, although not purposefully intended to cause disruption; and all firms in the broad environment are affected by the disruption. Brexit, for example, is not a low probability, high impact event that occurs at short notice. There has been a massive build-up to the UK's exit from the EU, which puts greater emphasis on the role of preparing for the disruption. Hence, the role of sensing threats and opportunities is significant. This leads to Proposition 3:

Proposition 3: Disruptions caused by constitutional change are characterised by: long time horizons before the disruption; high certainty of the disruption; and their widespread effect. This puts greater emphasis on the 'sensing' stage of dynamic capabilities than is typical for other forms of supply chain disruption, and on the development of proactive strategies for building SCRes in the run up to constitutional change.

\section{Conclusions}

This paper has investigated the resilience of supply chains to constitutional change by examining the impact of Brexit on local food supply chains in the UK. Further, the dynamic capabilities theoretical lens has been used to understand how resilience can be built by sensing and seizing opportunities and threats, and transforming or reconfiguring business models, operations, and supply chains. The paper provides a contribution to the literature on supply chain resilience by providing the first empirical study of how firms are building resilience to constitutional change; by providing a rare study of resilience across multiple supply chain tiers; and by outlining how the characteristics of the threat posed by constitutional change differ from the characteristics of other threats more typically studied in the literature. Clearly the threat to supply chains presented by constitutional change such as that brought about by Brexit is different in its characteristics to the threat of natural disasters, financial crises, etc. and has thus been worthy of study in its own right. Moreover, this paper highlights the importance of the operations/supply chain fields engaging with policy/ constitutional change and demonstrates the role these fields can play in responding appropriately. Finally, the paper contributes to the literature on dynamic capabilities by highlighting the role of horizontal and vertical collaboration between supply chain actors in the sensing, seizing, and transforming process.

\subsection{Managerial and Policy Implications}

This research has implications for managers who need to develop their dynamic capabilities in order to build SCRes, as discussed above. For example, practitioners across the supply chain need to work together to influence the future shape of the constitution; and they need to take ownership of their own operations and reconfigure them where necessary to become more resilient to the threat posed by Brexit, such as by reducing their reliance on EU funding streams and trade. The study also has implications for agricultural policy. In particular, the findings suggest that there are significant risks associated with reducing the CAP subsidy as this is likely to lead to higher prices at the point of food consumption for the consumer, thereby extenuating food poverty problems and/or making UK food production less competitive, which threatens the 
economic sustainability of the sector as well as food safety standards. Thus there is a need for more research to consider the precise form that the replacement for CAP should take, but it is important that it: (i) incentivises good practice and operational excellence (e.g. in animal welfare and environmental practices); (ii) incentivises effective and sustainable use of resources (e.g. the countryside, given links to the tourism industry); (iii) discourages over-supply and waste; and (iv) supports rural communities to be business focused (for social sustainability).

\subsection{Limitations and Future Research}

This study has focused on the build-up to Brexit. It could therefore be interesting to conduct a further study after Brexit or to extend this research into a longitudinal multi-disciplinary study as the process of constitutional change unfolds. This would enable firms to reflect on events, threats, opportunities and their impact. It could also put greater emphasis on the seizing and transforming stages of the dynamic capabilities perspective and on the response and recovery stages of building resilience. Firms in the EU will also be affected by Brexit as it will impact the EU as a whole and the trade relations between the UK and the EU as well as between individual firms in the UK and EU. It could therefore also be valuable to look at how actors in mainland Europe that are remaining in the EU are also preparing for and responding to Brexit.

\section{References}

Ahn J.M., Mortara L., \& Minshall T. (2018), Dynamic capabilities and economic crises: has openness enhanced a firm's performance in an economic downturn? Industrial and Corporate Change, 27(1), 49-63.

Ali, A., Mahfouz, A., \& Arisha, A., (2017). Analysing supply chain resilience: Integrating the constructs in a concept mapping framework via a systematic literature review. Supply Chain Management: An International Journal, 22(1), 16-39.

Allouche, J. (2011). The sustainability and resilience of global water and food systems: Political analysis of the interplay between security, resource scarcity, political systems and global trade. Food Policy, 36, S3-S8.

Ambulkar, S., Blackhurst, J., \& Grawe, S., (2015). Firm's resilience to supply chain disruptions: Scale development and empirical examination. Journal of Operations Management, 33-34, 111-122.

Augère-Granier, M-L., (2016). Short food supply chains and local food systems in the EU, Briefing paper for European Parliamentary Research Service, Sept 2016.

Barthel, S., Parker, J., \& Ernstson, H. (2015). Food and green space in cities: A resilience lens on gardens and urban environmental movements. Urban studies, 52(7), 1321-1338.

Barreto, I. (2010). Dynamic Capabilities: A review of past research and an agenda for the future. Journal of Management, 36(1), 256-280.

Benton, T., Crawford J., Doherty, B., Fastoso, F., Gonzalez Jimenez, H., Ingram, J., Lang, T., Smith, P. \& Tiffin, R. (2017). British food: What role should UK producers have in feeding the UK? http://www.morrisons-corporate.com/Global/localfoodmakers/BritishFood ReportFeb2017.pdf

Blackhurst, J., Dunn, S., \& Craighead, W., (2011). An empirically derived framework of global supply resiliency. Journal of Business Logistics, 32(4), 374-391.

Boone, C., Craighead, C., Hanna, B., \& Nair, A. (2013). Implementation of a System Approach for Enhanced Supply Chain Continuity and Resiliency: A Longitudinal Study. Journal of Business Logistics, 34(3), 222-235. 
Brandon-Jones, E., Squire, B., Autry, C., \& Petersen, K., (2014). A contingent Resource-Based perspective of supply chain resilience and robustness. Journal of Supply Chain Management, 50(3), 55-73.

Brunori, G. \& Galli, F. (2016). Sustainability of Local and Global Food Chains: Introduction to the Special Issue, Sustainability, 8(8), 1-7.

Carpenter, S.R., Westley, F. \& Turner, G. (2005). Surrogates for resilience of socialecological systems. Ecosystems, 8(8), 941-944.

Carvalho, H., Maleki, M., \& Cruz-Machado, V. (2012). The links between supply chain disturbances and resilience strategies. International Journal of Agile Systems and Management, 5(3), 203-234.

Czinkota, M., Kaufmann, H.R. \& Basile, G., (2014). The relationship between legitimacy, reputation, sustainability and branding for companies and their supply chains. Industrial Marketing Management, 43, 91-101.

Dabhilkar, M., Birkie, S.E., \& Kaulio, M., (2016). Supply-side resilience as practice bundles: A critical incident study. International Journal of Operations \& Production Management, 36(8), 948-970.

Day, M., (2014). Fostering emergent resilience: the complex adaptive supply network of disaster relief. International Journal of Production Research, 52(7), 1970-1988.

Davoudi, S. (2012). Resilience: A bridging concept or a dead end? Planning Theory \& Practice, 13(2), 299-333.

de Lima, F.R.P., Da Silva, A.L., Filho, M.G., \& Dias, E.M. (2018). Systematic review: resilience enablers to combat counterfeit medicines. Supply Chain Management: An International Journal.

Eisenhardt, K.M. \& Martin, J.A., (2000). Dynamic capabilities: What are they? Strategic Management Journal, 21(10/11), 1105-1122.

Folke, C., Carpenter S., Walker, B., Scheffer, M., Chapin, T. \& Rockström, J. (2010). Resilience Thinking: Integrating Resilience, Adaptability and Transformability. Ecology and Society, 15(4), 20-28.

Gebauer, H., (2011). Exploring the contribution of management innovation to the evolution of dynamic capabilities. Industrial Marketing Management, 40(8), 12381250.

Gibbert, M., Ruigrok, W. \& Wicki, B., (2008). What passes as a rigorous case study? Strategic Management Journal, 29(13), 1465-1474.

Gunderson, L.H. \& Holling, C.S. (editors), (2002). Panarchy: Understanding Transformations in Human and Natural Systems. Island Press, Washington, D.C., USA.

Hohenstein, N., Feisel, E., Hartmann, E., \& Giunipero, L., (2015). Research on the phenomenon of supply chain resilience. International Journal of Physical Distribution \& Logistics Management, 45(1-2), 90 - 117.

Holling, C.S., (1973). Resilience and stability of ecological systems. Annual Review of Ecology and Systematics, 4, 1-23.

Holling, C.S., (1996). Engineering resilience versus ecological resilience. In: Schulze, P.C. (editor): Engineering Within Ecological Constraints, 31-45. National Academy Press.

Hollnagel, E. (2011), Epilogue: RAG: the resilience analysis grid, in Hollnagel, E., Paries, J., Woods, D. and Wreathall, J. (Eds), Resilience Engineering in Practice: $A$ Guidebook, Ashgate Press, Surrey, 275-296.

Johnson, N., Elliott, D., \& Drake, P., (2013). Exploring the role of social capital in facilitating supply chain resilience. Supply Chain Management: An International Journal, 18(3), 324-336.

Jüttner, U. \& Maklan, S. (2011). Supply chain resilience in the global financial crisis: an empirical study. Supply Chain Management: An International Journal, 16(4), 246259. 
Ketokivi, M. \& Choi, T., (2014). Renaissance of case research as a scientific method. Journal of Operations Management, 32, 232-240.

Kim, Y., Chen, Y., \& Linderman, K., (2015). Supply network disruption and resilience: A network structural perspective. Journal of Operations Management, 33-34, 43-59.

Leat, P., \& Revoredo-Giha, C., (2013). Risk and resilience in agri-food supply chains: The case of the ASDA pork link supply chain in Scotland. Supply Chain Management: An International Journal, 18(2), 219 - 231.

Maggio A., Van Criekinge, T., Malingreau, J.-P., (2016). Global food security: assessing trends in view of guiding future EU policies, Foresight, 18(5), 551-560.

Mandal, S., (2012). An empirical investigation into supply chain resilience. The IUP Journal of Supply Chain Management, 9(4), 46-61.

Marucheck, A., Greis, N., Mena, C., \& Cai, L., (2011). Product safety and security in the global supply chain: Issues, challenges and research opportunities. Journal of Operations Management, 29(7), 707-720.

Oglethorpe, D. \& Heron, G., (2013). Testing the theory of constraints in UK local food supply chains. International Journal of Operations \& Production Management, 33, 1346-1367.

Pettit, J., Fiksel. J., \& Croxton, K., (2010). Ensuring supply chain resilience: Development of a conceptual frame work. Journal of Business Logistics, 31(1), 1-21.

Pettit, J., Croxton, K., \& Fiksel, J., (2013). Ensuring Supply Chain Resilience: Development and Implementation of an Assessment Tool. Journal of Business Logistics 34(1), 46-76.

Ponis, S., \& Koronis, E., (2012). Supply chain resilience: definition of concept and its formative elements. Journal of Applied Business Research, 28(5), 921-930.

Ponomarov, S., \& Holcomb, C., (2009). Understanding the concept of supply chain resilience. International Journal of Logistics Management, 20(1), 124 - 143.

Pullman, M.E. \& Dillard, J. (2010). Values based supply chain management and emergent organizational structures. International Journal of Operations \& Production Management, 30(7), 744-771.

Reuter, C., Foerstl, K., Hartmann, E. \& Blome, C., (2010). Sustainable global supplier management: the role of dynamic capabilities in achieving competitive advantage. Journal of Supply Chain Management, 46(2), 45-63.

Rice, J. \& Caniato, F. (2003). Building a secure and resilient supply network. Supply Chain Management Review, 7(5), 22-30.

Rockström, J., Falkenmark, M., Karlberg, L., Hoff, H., Rost, S., \& Gerten, D. (2009). Future water availability for global food production: the potential of green water for increasing resilience to global change. Water Resources Research, 45(7), 1-16.

Rojo, A., Stevenson, M., Lloréns Montes, F.J., \& Perez-Arostegui, M.N. (2018). Supply chain flexibility in dynamic environments: The enabling role of operational absorptive capacity and organisational learning. International Journal of Operations \& Production Management, 38(3), 636-666.

Ridder, H-G, (2017). The theory contribution of case study research designs. Business Research, 10, 281-305

Scholten, K., \& Schilder, S., (2015). The role of collaboration in supply chain resilience. Supply Chain Management: An International Journal, 20(4), 471-484.

Scholten, K., Scott, P., \& Fynes, B., (2014). Mitigation processes - antecedents for building supply chain resilience. Supply Chain Management: An International Journal, 19(2), 211-228.

Sheffi, Y. (2005). Building a resilient supply chain. Harvard Business Review, 1(8), 1-11.

Sheffi, Y. \& Rice, J. (2005). A supply chain view of the resilient enterprise. MIT Sloan management review, 47(1), 41-48.

Simangunsong, E., Hendry, L.C., \& Stevenson, M. (2012). Supply-chain uncertainty: a review and theoretical foundation for future research. International Journal of Production Research, 50(16), 4493-4523. 
Simangunsong, E., Hendry, L.C., \& Stevenson, M. (2016). Managing supply chain uncertainty with emerging ethical issues. International Journal of Operations \& Production Management, 36(10), 1272-1307.

Stevenson, M., \& Busby, J. (2015). An exploratory analysis of counterfeiting strategies: Towards counterfeit-resilient supply chains. International Journal of Operations \& Production Management, 35(1), 110-144.

Stone, J., \& Rahimifard, S. (2018). Resilience in agri-food supply chains: a critical analysis of the literature and synthesis of a novel framework. Supply Chain Management: An International Journal, https://doi.org/10.1108/SCM-06-2017-0201.

Tang, C. (2006a). Perspectives in supply chain risk management. International Journal of Production Economics, 103(2), 451-488.

Tang, C. (2006b). Robust strategies for mitigating supply chain disruptions. International Journal of Logistics: Research and Applications, 9(1), 33-45.

Teece, D.J., (2007). Explicating dynamic capabilities: The nature and micro foundations of (sustainable) enterprise performance. Strategic Management Journal, $28,1319-1350$.

Teece, D.J., Pisano, G. \& Shuen, A., (1997). Dynamic capabilities and strategic management. Strategic Management Journal, 18(7), 509-533.

Tukamuhabwa B.R, Stevenson M., Busby J. \& Zorzini M., (2015). Supply chain resilience: definition, review and theoretical foundations for future studies. International Journal of Production Research, 53(18), 5592-5623.

Tukamuhabwa, B., Stevenson, M., \& Busby, J. (2017). Supply chain resilience in a developing country context: a case study on the interconnectedness of threats, strategies and outcomes. Supply Chain Management: An International Journal, 22(6), 486-505.

Urciuoli, L., Mohanty, S., Hintsa, J., \& Boekesteijn, E., (2014). The resilience of energy supply chains: A multiple case study approach on oil and gas supply chains to Europe. Supply Chain Management: An International Journal, 19(1), 46-63.

Van der Vegt G.S., Essens, P., Wahlström, M., \& George, G., (2015), Managing Risk and Resilience. Academy of Management Journal, 58(4), 971-980.

Van der Vorst, J.G.A.J., Beulens, A.J., Wit, W.D., \& Beek, P.V. (1998). Supply chain management in food chains: Improving performance by reducing uncertainty. International Transactions in Operational Research, 5(6), 487-499.

Voss, C., Johnson, M. \& Godsell, J., (2016). Case Research. In: Karlsson, C. (Ed), Research Methods for Operations Management, $2^{\text {nd }}$ Edition, Routledge, New York, 165-197.

Vlajic, J.V., Van der Vorst, J.G., \& Haijema, R. (2012). A framework for designing robust food supply chains. International Journal of Production Economics, 137(1), 176-189.

Wang, X., Herty, M., \& Zhao, L. (2016). Contingent rerouting for enhancing supply chain resilience from supplier behavior perspective. International Transactions in Operational Research, 23(4), 775-796.

Wieland, A. \& Wallenburg, C. (2013). The influence of relational competencies on supply chain resilience: A relational view. International Journal of Physical Distribution \& Logistics Management, 43(4), 300 - 320.

Wilhelm, M., Blome, C., Weick, E. \& Xiao, C.Y. (2016). Implementing sustainability in multi-tier supply chains: Strategies and contingencies in managing sub-suppliers. International Journal of Production Economics, 182, 196-212.

Yin, R.K. (2018). Case study research and applications: Design and methods, $6^{\text {th }}$ edition, California, Sage Publications.

Zorzini, M., Hendry, L.C., Huq, F.A. \& Stevenson, M., (2015). Socially responsible sourcing: reviewing the literature and its use of theory. International Journal of Operations \& Production Management, 35(1), 60-109. 


\section{Biographical Details:}

Professor Linda Hendry: Linda Hendry is a Professor of Operations Management at Lancaster University Management School, UK. Her research interests include: global supply chain management, including sustainable sourcing and supply chain responses to modern slavery legislation; manufacturing strategy, planning \& control for product customisation contexts; and process improvement approaches, such as Six Sigma. Linda is a member of the European Operations Management Association (and was formerly on the Board as a member of the Finance Team). She has published extensively in a wide variety of journals, including those that focus on Supply Chain Management, Operations Management, Production and Operational Research.

Professor Mark Stevenson: Mark Stevenson is a Professor of Operations Management at Lancaster University in the UK. His research interests currently include sustainable supply chain management, supply chain risk and resilience, supply chain flexibility and uncertainty, production planning \& control in high-variety manufacturing companies, and reshoring \& the manufacturing location decision. His work has appeared in several operations and supply chain journals, including the International Journal of Operations \& Production Management (IJOPM), Production \& Operations Management (POM), the International Journal of Production Economics (IJPE), the International Journal of Production Research (IJPR), and Supply Chain Management: An International Journal (SCMIJ). He regularly attends and presents his work at international conferences, including the European Operations Management Association (EurOMA) conference.

Professor Jill MacBryde: Jill MacBryde is Deputy Dean and Head of the Operations Management Group at The York Management School. The theme throughout Jill's work is operations management in changing environments. Jill engages in collaborative research, often reaching across disciplinary boundaries. Jill's "laboratory" is industry and she engages in useful research whilst at the same time helping to bring about significant improvements in business performance. Jill strives to ensure that her academic research, teaching and knowledge exchange activities feed off each other. Prior to moving to York Jill was ViceDean for Knowledge Exchange at Strathclyde Business School.

Professor Peter Ball: Peter Ball belongs to the Operations Management Group at The York School of Management. His research focuses on how manufacturing operations can be designed and improved. Application areas span manufacturing, supply chain and service. His research takes a 'hard' view of processes by developing and applying modelling and simulation techniques to understand performance as well as a 'soft' view of processes by creating and capturing methods and practices that underpin performance. Environmental sustainability and resource efficiency feature strongly. Prior to moving to York, Peter was Director of Education for his school in Cranfield University.

Dr Maysara Sayed: Maysara Sayed is a Research Fellow at Edinburgh University, having completed his doctoral studies in the Management Science Department at Lancaster University Management School, UK. His research interests include: sustainability in supply chain management, manufacturing and service operations - particularly including the public sector, procurement management, logistics management and the use of data science in supply chain management. Maysara is a member of the European Operations Management Association (EurOMA) and his research has appeared in operations and supply chain journals such as Supply Chain Management: An International Journal (SCMIJ) as well as presented at several EurOMA conferences, including the main annual conference and the International EurOMA Sustainable Operations and Supply Chain Forum.

Dr Lingxuan Liu: Lingxuan Liu is a Lecturer of Sustainability at Lancaster University Management School. His research interests include sustainable supply chains, corporate sustainability strategies, environmental information disclosure \& reporting, environmental policy and climate policy. Prior to Lancaster, he was the Lead Researcher, Greater China of The Sustainability Consortium, which is a leading global non-profit organization that works on supply chain sustainability reporting of consumer products in all major sectors. He completed PhD study in Nanjing University of China on environmental management and policy, during which he managed several research programs about eco-industrial parks and regional environmental policies. He also spent two years in University of California, Santa Barbara for an exchange program on environmental governance. 